Portland State University

PDXScholar

3-1-2018

\title{
bodysecrecy: State Surveillance and Black Feminist Refusal
}

\author{
Alex León Herrera \\ Portland State University
}

Follow this and additional works at: https://pdxscholar.library.pdx.edu/honorstheses Let us know how access to this document benefits you.

\section{Recommended Citation}

Herrera, Alex León, "bodysecrecy: State Surveillance and Black Feminist Refusal" (2018). University Honors Theses. Paper 524.

https://doi.org/10.15760/honors.529

This Thesis is brought to you for free and open access. It has been accepted for inclusion in University Honors Theses by an authorized administrator of PDXScholar. Please contact us if we can make this document more accessible: pdxscholar@pdx.edu. 
bodysecrecy: state surveillance and Black feminist refusal

by

\section{Alex León Herrera}

an undergraduate honors thesis submitted in partial fulfillment of the requirements for the degree of bachelor of arts

in

university honors

and

political science

thesis adviser

Derrais Carter

portland state university 


\section{introduction and background}

categorical human hierarchy is a primary component of western societies. the observation, subjugation, and storytelling of the body and flesh produce a system of definitions and names that are integral to how we define the human. in Demonic Grounds, Katherine McKittrick writes " $[. .$.$] it is not a natural system, but rather a working system that manages the$ social world"1 where "these hierarchies are naturalized by repetitively spatializing 'difference.",2 through this system, we rationalize the world and place stereotyped and caste imaginations on the ways a body should comport itself based on its position in the hierarchy. this is a violent process, one that racializes and genders us all, yet remains particularly invested in the regulation of Black women, the very people who stand at the intersections of these processes.

surveillance reinforces and regulates white imagined visual logic about Black women's bodies. said bodies have been mapped onto specific images, such as "stereotypical mammies, matriarchs, welfare recipients, and hot mamas" as a way to "justify [their] oppression."3 Black women's bodies are always already visible through what McKittrick calls a "bodily code" that "means her place and body are seen to be, and understood as naturally subordinate to whiteness and masculinity." this process results in a visual essentialism, allowing only a limited few understandings of Black women and their ways of being.

this project examines the ways Black women in film subvert or refuse controlling images through a practice of bodysecrecy. defined by M. NourbeSe Philip as the mechanism that codes the body as knowable, bodymemory ${ }^{5}$ is the tool by which "the Black body is seen and inscribed

\footnotetext{
${ }^{1}$ Katherine McKittrick, Demonic Grounds: Black Women and the Cartographies of Struggle, xvi.

2 Ibid, xv.

${ }^{3}$ Patricia Hill Collins, Black Feminist Thought: Knowledge, Consciousness, and the Politics of Empowerment, 69.

${ }^{4}$ McKittrick, 40.

${ }^{5}$ M. NourbeSe Philip, “African Roots and Continuities: Race, Space and the Poetics of Moving,” 201-33.
} 
under the rubric of privileged visual ideology"6; wherein Black women are made permanently locatable. grounded in the work of Black feminist/womanist scholars, poets, social theorists, and activists, I argue that the Black women protagonists in John Berry's Claudine (1974) and Haile Gerima's Bush Mama (1979) use dissemblance and bodysecrecy to resist state surveillance and claim control over their bodies.

\section{literature review}

In Dark Matters: On the Surveillance of Blackness, Simone Brown explores the ways in which the carceral state develops and maintains control over Black life through surveillance - to understand the development of "surveillance in and of Black life as a fact of Blackness."7 Browne's thesis is grounded in Sylvia Wynter's "sociogenic principle" or sociogeny, "the organizational framework of our present human condition that names what is and what is not bounded within the category of the human, and that fixes and frames Blackness as an object of surveillance." ${ }^{\prime 8}$ this defines Blackness as a functional understanding, modality, and way of being that is readable within social spaces, in texts, and on screens. this surveillance, then, becomes a mechanism for control, where images of Blackness are projected onto the psyche in order to dictate what is and isn't out of place. Browne's “chapter 3: 'B $\mathrm{R}$ anding Blackness: Biometric Technology and the Surveillance of Blackness" further explores the nature of surveillance as a tool of the state for control and meaning making. by examining colonial technologies of branding and "the tracking of Blackness as property," and tracing the transformation of the practice into current racialized surveillance, Browne gives context for the process that produces

\footnotetext{
${ }^{6}$ McKittrick, 49.

${ }^{7}$ Browne, Simone. Dark Matters: On the Surveillance of Blackness, 6.

${ }^{8}$ Browne, 7.

${ }^{9}$ Ibid. 91.
} 
understandings of Black flesh. in essence, what was once the branding of flesh with iron and steel, is now manifest in the epidermalization of Blackness. the inscription of race on the flesh allows the body to be defined by the state and controlled through its permanent visual location. in "Mammies, Matriarchs, and Other Controlling Images," sociologist Patricia Hill Collins uses the term "controlling images" to demonstrate how images of Black women reinforce elite white (heterosexual) male ways of seeing the world. the first image, the mammy, carefully crafted in the antebellum United States, is based in the understanding of Black women as asexual caretakers, devoted to the wellbeing of white families. this stereotype, while based in the realities of Black female servitude during enslavement and the reconstruction era, manifests today in the typified Black mother in white homes. Hill Collins contrasts the mammy image with the second, the matriarch. this character attempts to explain why "Black family structures are seen as being deviant because they challenge the patriarchal assumptions underpinning the traditional family ideal." ${ }^{\prime 10}$ the Black matriarch is blamed for stripping Black men of their authority as patriarchs. the image of the Black welfare queen is exacerbated by the white imaginary and particularly by the state. this is used to fabricate justification for the surveillance and control of Black mothers as a social service. the final image explored by Hill Collins is that of the jezebel/hoochie, a hypersexual woman with no self-control. this image relies on the sexual normative/deviant binary in order to cast Black women as other.

while Browne and Hill Collins focus their lens on the tools of subjugation and domination of Black female bodies, Darlene Clark Hine hones in on an account of what happens when Black women respond to such tools of warfare. in "Rape and the Inner Lives of Black Women in the Middle West," Hine writes a historical narrative of Black women's refusal through dissemblance, meaning "the behavior and attitudes of Black women that created the

\footnotetext{
${ }^{10}$ Hill Collins, 77.
} 
appearance of openness and disclosure but actually shielded the truth of their inner lives and selves from their oppressors." ${ }^{11}$ in this work, she explores dissemblance in the form of Black female migration from the sexually exploitative southern US in the name of claiming bodily control. as opposed to elsewhere, where scholars have considered control in the form of surveillance, here we understand the tool of control to be sexual exploitation and rape. Hine highlights the ways Black women were able to utilize their "marginal" position in society to craft a "veil of secrecy," and further, to flee the sexual subordination they faced in the southern United States with little attention from white southerners. Black female migration was a prime example of Black feminist refusal and bodily reclamation.

together, these scholars are seminal to understanding and evaluating the ways Black women employ veils of secrecy in order to survive and build community. one of the most prolific scholars on this topic is one Hortense Spillers, who begins her essay Mama's Baby, Papa's Maybe: An American Grammar Book with a "locus of confounded identities, a meeting ground of investments and privations in the national treasury of rhetorical wealth" ${ }^{12}$ with which to identify the names and positions of Black women that are a number of things (insert Hill Collins' work here) but never human. she goes on to assert that the names she wears in public spaces as a Black woman are all prescribed her by categorical human hierarchies that retain Black women as property, prohibited to name oneself. beginning with the theft and enslavement of Africans, where colonial thought was forged on those stolen bodies, this concept of humans as property takes on deeper meaning and Spillers addresses the ways that the installation of male/female genders as well as ethnicity mark the body as seeable, presumably knowable, and therefore belonging to those who crafted such categories. "the captivating party does not only earn the

\footnotetext{
${ }^{11}$ Hine, Darlene Clark. "Rape and the Inner Lives of Black Women in the Middle West," 912.

${ }^{12}$ Spillers, Hortense. Black, White, and in Color, 203.
} 
right to dispose of the captive body as it sees fit, but gains, consequently, the right to name and 'name' it [...]." ${ }^{\prime 13}$ these names prescribed upon the African body are then translated into bodily codes by Europeans through literature, science, the arts, and law; where "[...] a kind of diasporic racialized subject gets put into place as a result of the violence of the transatlantic slave trade." 14 taking the conversation further, Spillers addresses the lack of ownership allowed Black bodies "the enslaved as property identifies the most familiar element of a startling proposition. but to overlap kinlessness on the requirements of property might enlarge our view of the conditions of enslavement" community." 16 this analysis of Black women's positions butts heads with the "pathological Black matriarch" character and forces a questioning of how Black women can be defined by those that negate their definitions. this imagination of the slave as not being a person, yet holding a very specific narrative is what Spillers hones in on. the white imagined Black female body reaps a faulty definition that both aligns with and defies their meanings of reality.

Katherine McKittrick uses Hortense Spillers' work to examine the cartographies of Black women and specifically, the theory and practice of dissemblance. picking back up on the discussion around categorical human hierarchy, McKittrick argues that "existing cartographic rules unjustly organize human hierarchies in place and reify uneven geographies in familiar, seemingly natural way" "17; however, she reveres the fact that "these rules are alterable and there exists a terrain through which different geographic stories can be and are told." 18 the integral

\footnotetext{
13 Spillers, 210.

14 Eversley, Shelly, et al. “'Whatcha Gonna Do?': Revisiting 'Mama’s Baby, Papa's Maybe: An American Grammar Book’: A Conversation with Hortense Spillers, Saidiya Hartman, Farah Jasmine Griffin, Shelly Eversley, \& Jennifer L. Morgan," 305.

15 Spillers, 217.

16 Ibid. 218.

${ }^{17}$ McKittrick, Katherine. Demonic Grounds: Black Women And The Cartographies Of Struggle, x.

18 Ibid. $\mathrm{x}$.
} 
connection between Blackness and space here is reminiscent of Simone Browne's work around surveillance and bodily codes. Black life and Black women specifically are tied to the physical geographies of space and place (i.e. cities, plantations, the home), as well as the liminal geographies of definition and narrative. Black women are rendered locatable by the controlling images explored by Hill Collins and thus become placed within "geographies of domination."19 as much as Blackness matters in spatializing and characterizing difference, so does gender. this is why Black female bodies occupy such particular space. further, McKittrick argues that the Black woman is in fact made tool for defining whiteness and maleness; "Black women necessarily contribute to a re-presentation of human geography." ${ }^{20}$ her work in Demonic Grounds is meant to weave together understandings of discursive technologies in order to focus the lens on Black women and the spaces they do/don't hold in society. within the second chapter of this text - "The Last Place They Thought of: Black Women's Geographies" - McKittrick defines Black women's space as paradoxical, being subordinate to whiteness and maleness, yet remaining crucial to those constructs.

\section{method}

in Dark Matters, sociologist Simone Browne maps an etymology of surveillance writing “surveillance is understood here as meaning 'oversight,' with the French prefix sur-meaning 'from above' and the root word-veillance deriving from the French verb veiller and taken to mean observing or watching." ${ }^{21}$ this definition lays a framework for general use, and requires a further nuanced assessment that says that surveillance manifests in a particular manner when fixated on Black bodies in the United States.

\footnotetext{
${ }^{19}$ Ibid. xv.

${ }^{20}$ Ibid. xxv.

${ }^{21}$ Browne, 18.
} 
throughout this thesis, surveillance is operationalized by the state as a tool to monitor and maintain a white supremacist patriarchal order. this oversight takes place in the context of social services, specifically welfare, forcing Black mothers into a liminal space of being. I use surveillance, dissemblance, bodymemory, and bodysecrecy to address and assess the ways Black women in the films and interact with the state, and vice versa.

historian Darlene Clark Hine theorizes "dissemblance” to reveal how Black women employ a veil of secrecy to "protect the sanctity of inner aspects of their lives." 22 this phenomenon takes shape in two ways; the performance of openness by Black women, and the concealment of truth. this first part of dissemblance explains the ways in which Black women perform vulnerability as a means of survival. throughout this essay, this is exemplified by Black mothers engaging with social services and welfare, where they are forced to show up in a very specific way and allow the state access to their lives. the second part addresses the veil of secrecy, under which Black women live freely and unto themselves, in a manner the state never sees. this definition of dissemblance bleeds into my definition of bodysececy which is, in essence, the process by which Black women dissemble from the bodily code. ${ }^{23}$ I take bodymemory to explain the ascribed social location of bodies deemed to be Black and women. the logic of categorization that is developed through technologies of state surveillance. bodysecrecy takes up explaining the work being done when Black women imagine themselves responding truly to the violences of the state, yet outwardly appear unphased and compliant. dissemblance and bodysecrecy work in tandem to subvert surveillance tactics of the state.

\footnotetext{
${ }^{22}$ Darlene Clark Hine, "Rape and the Inner Lives of Black Women in the Middle West," 915.

23 bodysecrecy hinges on M. NourbeSe Philip's bodymemory, which is appropriated by Katherine McKittrick and defined as '[...] a corporeal continuity, which moves through time and recognizes where 'permanent' racial-sexual time-spaces appear $[\ldots] .{ }^{.23}$
} 


\section{film analysis - Bush Mama (1979)}

film overview

Haile Gerima's Bush Mama (1979) is an icon of the 1970's LA Rebellion's experimental Black film canon. the film takes up the narrative of a Black woman named Dorothy (Barbara O. Jones) in the throes of the sociopolitical ricochets of the prison industrial complex as her husband, TC (Johnny Weathers), is incarcerated. a film shot in entirely black and white, Bush Mama is stylistically unique and chock full of symbolism and nuanced iconography that represent the omnipresence of the state and police violence in Los Angeles and in the Black home.

the film begins with footage of Gerima and his film crew being harassed by police officers whilst filming the movie. in the middle of a Los Angeles street, police search the camera crew, pushing them up against police cars, moving equipment around, and interrogating the Black filmmakers. the footage of the encounter is shot from above, presumably from a building window or traffic camera. the view we get of the interaction is a metaphor for the watchful eye of the state, both on the ground (police in cars) and from above (some camera in the distance). though there is no dialogue or plot-driven interaction, Gerima includes this footage in the final cut of the film in order to demonstrate how easy it is for the state to insert itself into Black life; even, ironically, while telling stories about state violence in Black life. in her work, Dark Matters: On the Surveillance of Blackness, Simone Browne writes “Oscar Gandy’s 'panoptic sort' names the process by which the collection of data on and about individuals and groups as 'citizens, employees and consumers' is used to identify, classify, assess, sort, or otherwise "control their access to the goods and services that define life in the modern capitalist society." 24

24 Browne, 16. 
this explains Gerima's use of non diegetic readings of welfare questionnaires during this first scene, and later throughout the film.

the film follows Dorothy, who is required to navigate welfare systems while her husband $\mathrm{TC}$ is in prison for a murder he didn't commit. throughout the film, we see Dorothy inundated with questions and demands from welfare services and her community. not only does Dorothy have a daughter, but she is also pregnant with TC's child, whom the welfare office tries to convince her to abort. the ever presence of the state in Dorothy's life is represented throughout the film, most notably in the forms of audio recordings of welfare survey questions and nondiegetic sounds of people heckling Dorothy.

as the film progresses, TC becomes radicalized while in prison, reading Black nationalist literature and writing to Dorothy about them. she brings his thoughts and messages to her friends in an attempt to unpack the oppressive systems (i.e. the white supremacy, police, slavery, and prisons) that TC talks about. her friends, family, and community dismiss Black radicalism, claiming that white people and whiteness have never caused them ill; and that even though they can recognize the state has taken so much from them - be it their privacy, their jobs, or their loved ones - that radicalizing is useless. despite this, Dorothy continues to have TC's letters read to her. at the same time, her friends daughter whom she watches is learning about the Black rebellion and acts as a liaison to Dorothy about the youth and Black radical movements that Dorothy can’t necessarily access without risking welfare access or community criticism.

violence is a key theme throughout the film, pertaining to state sanctioned violence of police and prison guards, but also in the evolution of Dorothy's character. it is state sanctioned police violence that starts the film, with the apprehension and harassment of Gerima himself. violence manifests in a number of scenes throughout: outside the welfare office where a Black 
man is shot dead by police, in the post traumatic stress that plagues TC after his stint in the military, in the final scene where Dorothy's daughter, Luan is raped by a police officer and where Dorothy subsequently kills him and then is beaten by police as consequence. this violence is narrated throughout by the slow awakening of Dorothy's political consciousness. as she is made more aware of the violence, so too does she see it permeating the means by which the state watches her, her daughter, her husband, and her friends and community. the violence carried out is a direct result of the state's ability to infiltrate her home, whether by virtue (the welfare visits) or by force (police). it is no coincidence that TC's situation (having fought in Vietnam and engaging with Black nationalism from prison) parallel with the fact that "the vast expansion of state surveillance in the 1960 s was a response to the new militancy of the movements against the imperialist war in Vietnam and for civil rights and Black liberation." ${ }^{25}$ this film takes place at a time when the state was making moves from outside of civil society (looking down from above) and transitioning to operating within civil society through social services, signal surveillance, etc. ${ }^{26}$ as Dorothy's consciousness grows, so does her inclination towards violence. she imagines herself reacting violently to welfare workers - slapping them across the face - and at the end of the film commits an act of violence to protect her child who is being raped by a police officer. as a result of her violence, Dorothy is arrested and beaten to the loss of her unborn child, alluding to the state's ability to control Black life overtly or inadvertently.

scene 1 - advising Dorothy (7:18 - 10:45)

the earliest interaction between Dorothy and social services occurs seven minutes into the film after a mentally ill Black man is shot and killed by the police outside the welfare office. the

\footnotetext{
${ }^{25}$ Kumar and Kundnani, 32.

${ }^{26}$ Ibid.
} 
scene follows Dorothy and a welfare worker down a small hallway, the worker is asking her questions about her daughter, Luan; and gives her advice that she should have an abortion of the child she is pregnant with now, seeing that her husband is in prison.

as Dorothy and the welfare office worker walk down the hall, Dorothy says nothing. the worker speaks at her with little response from Dorothy. the welfare agent recommends Dorothy get an abortion due to the fact that there is no man in the house since TC's arrest, and having a baby would jeopardize her welfare qualifications, making her look like a jezebel ${ }^{27}$ with no ability to care for her children (the assumption being that she is pregnant with another man's child). here. we should invoke Patricia Hill Collins's work around the controlling images of black women in the white imaginary. the warning the welfare worker tries to give is one that says that while Dorothy may be carrying TC's child, no one will believe it; thus she will appear promiscuous and unfit to mother. the jezebel image defined by Hill Collins is used here, demonizing a Black woman for the non-normative state of her family, painting her as deviant and undeserving of the services she seeks. Dorothy's reaction to these assertions is monotonous. she remains silent at the suggestion of an abortion, and internalizes the pain it might cause her. nowhere in this scene does she resist the state's hand reaching into her life, her choice, her womb.

the scene cuts to a white room where Dorothy is sitting in a circle with other Black people who are yelling obscenities and accusations at her. they call her stupid, a drunk, and a moocher; all with the pretense that she is unfit to be a mother, and is trying to take advantage of the state. there are Black men and Black women involved in the berating of Dorothy. she begins

${ }^{27}$ Hill Collins, 83 . 
to cry as they continue to yell at her and further, they make fun of her as she cries and TC appears to console her.

the peers who take to ridiculing and embarrassing Dorothy immediately after the scene in the welfare office take up the same work, reinforcing the image of the unfit and pathological Black mother. Black men and women stand around berating Dorothy with unfounded claims that she is a drunk, a poor mother, and a leech on the welfare system. these folks represent the pervasive nature of the controlling images of Black women that police and accuse them of being valueless and forcing them into subjugation by the white supremacist patriarchal state. these controlling images allow the US to market Black women's bodies as static beings in need of control. ${ }^{28}$ this need to control Black women makes itself manifest in "state agencies' use of demographic information to identify 'concentrations' of ethnically defined populations in order to target surveillance resources and to identify kinship networks can be utilized for the purposes of political policing." 29 these folks who may be kin to Dorothy in another context are used to reify and reinforce the narrative of the white patriarchal imaginary that forces Dorothy to cower in tears before TC appears to console her. the fact that the voices continue even after she is moved to tears is representative of the persistent violence and subjection to ridicule that Black mothers face within and without their communities, through state and community surveillance.

the scene dies out with a nondiegetic reading of a letter from TC that explains his drinking habits acquired in Vietnam, and begins to lay a foundation for understanding TC and Dorothy's story and situation. TC says that when he came back from the war, he didn't "qualify" for the housing and job benefits granted white soldiers and veterans upon their return. he had expected to be welcomed home with an air of heroism, but he was unable to gain employment

\footnotetext{
${ }^{28}$ Hill Collins, 84.

${ }^{29}$ Kumar and Kundnani, 23.
} 
and decided to re-enlist, promising Dorothy he would eventually get a job and move the family elsewhere. when TC was wrongfully arrested, a working class wage from odd jobs was absent from the family's home and that is what led Dorothy into the arms of the state.

this scene allows the audience a direct window into Dorothy's life and mind. these interactions between the state and her Black community are the primary definitions of her worth to the world. these are the voices she hears throughout the film, in Haile Gerima's unique and consistent use of nondiegetic sound. these people telling her who she is, what she should do, and how little she matters are what follow her around to the very end of the film, interrupting her thought and daily life at any given moment.

the insistence of state services upon Dorothy's body become a manifestation of control. surveillance "is a security logic that holds the imperial state as necessary to keeping 'american families' (coded white) safe from threats abroad and at home" ${ }^{30}$ - the essentialization of security forces and practices through the construction of fear and deviance. the controlling images presented to us by Patricia Hill Collins are used to craft a narrative of deviance in Black women. this deviance calls for the control and watchful eye of the state to intervene in Black life. in Dorothy's case, this is the welfare office and her peers expressing a distrust in her to mother a child. in the following scene, the state makes a physical penetration into Dorothy's home, furthering their agenda of control over her life.

scene 2 - welfare in the house (49:36 - 52:19)

the second and final scene between Dorothy and the welfare officer takes place in her home. the scene is spliced together with footage of Dorothy, her friends Molly and Simmi,

\footnotetext{
${ }^{30}$ Kumar and Kundnani, 38.
} 
around Simmi's dining table, arguing about Dorothy's drinking and whether or not she does drink. in the house, Dorothy sits on the sofa while the welfare officer stands in front of her, shouting about the empty liquor bottle in the side table, accusing Dorothy of being a drunk. Dorothy denies drinking, but does not seem particularly invested in anything the officer is saying, leading the officer to shout in attempt to get her point across.

again, the officer suggests Dorothy get an abortion, and writes down the name and address of the doctor she wants her to see. while she sits down to write the information, an alternate scene plays out where Dorothy stands up, picks up the empty liquor bottle, and smashes it on the officers head repeatedly. the "reality" of the scene resumes and Dorothy takes the recommendation scrawled out by the officer. Dorothy gets up to walk the officer to the apartment door and let her out. once the officer is out the door, Dorothy's daughter, Luan, runs into the room crying. Dorothy comforts her, telling her it will be okay, with no uncertainty in her voice. the poster on the wall is of an African mother, holding a gun in one arm and her baby in the other.

this scene prefaces and initiates a manifestation of violence exhibited by Dorothy. this is the first time we see the state penetrate the home, and make demands of Dorothy that she has no intention of filling. the positioning of the two women in this scene is vital to its representation. Dorothy is sat, slumped, on the couch while the officer stands above her, attempting to domineer. while both of them are Black women, they play different and almost oppositional roles. the officer acts as an agent of the state, a sociopolitical mammy for the white patriarchal state. Dorothy exhibits a hostility towards the officer, not allowing herself to appear invested in the narrative given to her, that of the welfare mother ${ }^{31}$, and "she claimed virulence, withholding the

${ }^{31}$ Ibid. 79. 
self-labor of purification as an assertion of humanity." 32 this is where the practice of dissemblance and bodysecrecy appear. Dorothy appears - externally - disinvested completely, all the while imagining a violent reality in which she smashes glass bottles on the heads of state agents. in her work No Mercy Here: Gender, Punishment and the Making of Jim Crow Modernity, Sarah Haley accounts for the stories and experiences of imprisoned Black women in chain gangs and early modern prison systems in the south. within this work she characterizes dissemblance as "the veil of secrecy with which Black women shrouded themselves was not merely reactive but a deliberate tactic to maintain personal autonomy and, in this case, escape imprisonment. Silence was the most common exit strategy." ${ }^{33}$ I use this quote to contextualize the work Dorothy does in the scene, even when it seems she is doing nothing. Dorothy's stifling of her impulse to smash the bottle on the social worker's head is a testament to the strategy of secrecy employed by Black women under surveillance.

Hortense Spillers tells us in “Mama’s Baby, Papa’s Maybe: an American Grammar Book" that Blackness and motherhood are in paradoxical relationship with each other, never able to meet the definition of the family as it is constructed under white patriarchal hegemony. this is true because, though a narrative is bestowed upon Black life, ownership cannot be claimed by that which is property. Dorothy is only granted agency insofar as it does not infringe upon the control that the state must maintain over her life; this necessarily pushes her ability to mother into a liminal space which is then used to reify the image of an inadequate and pathological motherhood. the scene ending with Luan and Dorothy hugging each other is a display of Black motherhood doing the best possible. though Dorothy knows she is facing an ultimatum of Black

\footnotetext{
${ }^{32}$ Sarah Haley, No Mercy Here: Gender, Punishment, and the Making of Jim Crow Modernity, 64.

${ }^{33}$ Ibid. 211.
} 
motherhood - whether to abort her child or bring into the world without the means to protect it she does not give up the effort to console her crying child, telling her that things will be okay.

this scene forms a sort of "next step" in the mission of the state to embed itself in Dorothy's life and remove her agency. in the first scene, Dorothy is on their terf so to speak - in the welfare office. in this scene, a transition happens and we see it take a toll on Dorothy in a way that pushes her to imagine a violent reactionary reality. if we view these scenes as a ladder, with the latitudinal pieces being state surveillance, and the horizontal steps being Dorothy's consciousness, we see an incline in both at the same time. the final scene exhibits the state's final and most intimate step into Dorothy's life, as well as the height of her fury in response and in refusal.

scene 3 - Dorothy's reckoning (1:32:59 - 01:37:12)

the final scene of the film depicts Dorothy walking in on her daughter Luan being raped by a police officer. the officer had been patrolling (surveying) their neighborhood and watching Luan outside of her apartment building, assessing whether or not she was alone. he takes her to the apartment where she is asked to prove she lives, and begins to rape her, handcuffed to the bed. mid-act, Dorothy arrives and reacts by leaping on top of the officer, and beating him to death with what an indiscernible object (appears to be a crowbar or a curtain track). the scene is spliced together with another of her in a holding cell, being questioned and then beaten by police officers for her crime. themes of violence are revisited from earlier in the film. ultimately, as she murders the rapist police officer, the police officers who arrest her beat her unborn baby to death inside of her. the pinnacle of events is sparked by the police officer operating as a tool of 
surveillance in the neighborhood, and then penetrating the home (as well as Luan). here we see a sort of "final stage" of state infiltration, as well as a "final stage" of action for Dorothy.

as the action dies down and Dorothy slides around in her and her baby's blood in a jail cell, non diegetic audio of her speaking begins. the film ends in a monologue from her to TC. she speaks about the ways the world has birthed her into a position, not of her own fault or making. she realizes and states that she has been caste to play a very particular role in society, one that she resents and no longer plans to play. "I been blaming myself all this time, because things ain't right. I thought I was born to be poor, pushed around and stepped on. I don't want Luan thinkin like that. I can see now our problem was a place I was born into." 34 this line highlights Dorothy's come to consciousness around what it means to live a prescribed life. this is the moment in which she acts on her impulse, rather than stifling them (re: scene 2) or remaining silent (re: scene 1). she asks TC to continue to write to her, teach her what he's learning, in a way she can read and pass on to Luan.

this final scene rounds out Gerima’s nonlinear narrative of Dorothy and her awakening. throughout the film we are thrown back and forth in time, overwhelmed at times with content and pervasive sound. at times, you feel lost in the film; having almost as little footing as Dorothy has throughout. though there are times she imagines responding genuinely to the state forcing itself on her, she is always acutely aware that retaliation is not strategic. it is only when the violence reaches her daughter that she is able to let herself act on feeling. because of this, the final scene brings the plot together in a fit of rage and passion and what I would call Black feminist refusal. in many ways, Dorothy's decision to attack her daughter's rapist was both instinctual and premeditated. as her political consciousness grows throughout the film, so does her inclination and curiosity around resistance and violence. she was enamored with the poster of

\footnotetext{
${ }^{34}$ Bush Mama, 1979.
} 
the African mother, protecting her baby with a gun, so much so that she glares at it for minutes, the mother's eyes following her throughout her home. Dorothy ends the final scene underneath the poster, her wig off, her child, however momentarily, protected.

Dorothy acknowledges the world that has brought her to this moment, accepts that she has always been fated for this. in many ways, the film Bush Mama is a reckoning; a cultural and political awakening of a Black mother come to understand her role in society, and then refuse it. she does not accept docility, nor the titles given to her by welfare officers or even friends and family. for a moment, she claims her child and asserts herself in the world even where she sees consequence. the last line she speaks in the film is "the wig is off my head," 35 or in other words "I am here and awake."

\section{film analysis - Claudine (1974)}

film overview

John Berry's Claudine, written by Tina and Lester Pine, attempts to explain the social performance exhibited by a Black mother in a 1970s US inner city under state surveillance. the film focuses on and follows Claudine Price (Diahann Carroll), a single Black mother of six living on welfare assistance in Harlem. over the course of the story we follow the embodiment of the Black matriarch through the throws of a new relationship, parenting challenges, and the tightrope walk of the united states welfare system.

we first meet Claudine on her way to work as a housekeeper for a white family in the suburbs. her community consists of other Black housekeepers who ride the bus together at the beginning and end of the day. this appears to be a valuable time and space for Claudine to exist away from her children, as well as apart from the white family she works for. the bus ride offers

\footnotetext{
${ }^{35}$ Bush Mama, 1979.
} 
a liminal space of comradery and mutual understanding among friends. Claudine meets Rupert Marshall (Roop) (James Earl Jones) as he collects garbage in the suburbs and woos her with his smooth talk and adamance at getting a date. Claudine agrees to a night out with Roop and he meets her later that evening at her home in Harlem, where we first meet her children. the Price children are at first hostile towards Roop, skeptical of his motivations with their mother. Roop takes Claudine to his home and the relationship flourishes quickly; the children growing to adore Roop. all the while, Claudine is maneuvering a tense relationship with the welfare/social worker, Miss Kabak, and trying to keep her children safe and off the streets.

the theme of surveillance is consistent throughout the film. the visits from Miss Kabak are the most potent examples of state surveillance in the home, but we see it also represented in dialogue between Claudine and Roop, Claudine and Charles, and the Black women on the bus. the soundtrack for the film, written by Curtis Mayfield and performed by Gladys Knight \& the Pips, sets this theme with the track revisited most throughout the film "Mr. Welfare Man" “Holding me back, using your tact, to make me live against my will, (hard sacrifice) // If that's how it goes child, I don't know, I can't concede my life's for real // It's like a private eye for the FBI." ${ }^{36}$

as the film progresses, we get a deeper look into what it means to be a Black mother in 1970s Harlem, where Black nationalism and militancy is on the rise, and state surveillance and policing is evolving at an incredible rate. the following scene analyses will examine Claudine's interactions with the state, as well as her performance of Black motherhood; all placed within the context of surveillance and Black feminist dissemblance.

scene 1 - Claudine and Roop's first date (18:26 - 21:34)

${ }^{36}$ Gladys Knight \& the Pips. Claudine (Original Motion Picture Soundtrack). (P) Buddha Records, 1974, audio. 
twenty minutes into the film, we enter Roop's apartment. in an effort to comfort a tired and nervous Claudine, Roop brings her to his home to bathe and get dressed before their first date. Roop draws her a bath and attempts to undress her before she scolds him and sends him away. while in the bathtub, Claudine falls asleep and Roop wakes her, after watching her sleep a few seconds first. when Claudine wakes, she is startled and attempts to cover herself and avert Roop's gaze. Roop remains persistent in his attention to her body, and suggests that rather than go out to dinner, they should order fried chicken and dine in his apartment. Claudine, slightly embarrassed, agrees; yet once Roop leaves the bathroom, Claudine leans back in the tub with a concerned and rattled expresion. the scene transitions to Roop's living room, where he has set a table with a yellow table cloth, fried chicken and red wine. Claudine calls her children to give them Roop's number in case of emergency while Roop prepares her seat.

as Claudine sits down to eat in a pink robe, Roop begins probing her with questions regarding her age and her children. Claudine snaps at Roop, acting a part that she typically associates with social workers and the welfare questionnaires. Claudine gets up and attempts to gather her things to leave, telling Roop he has no business asking her questions and expecting answers. Roop cowers at her ferocity and she begins to lob questions right back at him, about his loneliness, his children whom he never sees, and his past marriages. they both drink to their stereotypes of the absent Black father and the single Black mother. as this happens, Claudine and Roop are shifting from one end of the table to the other, and back and forth until Roop concedes, turns his charm back on, and Claudine is able to relax once more. the scene cuts to them in bed together.

Roop's persistence with Claudine is evident from the time they first engage on screen. his charm intrigues her and after slight resistance to him, she allows him to advance with careful 
consideration of all consequences. Claudine says throughout the film that she can never stop thinking - about her children, about the social worker, about Roop, about the future. every move she makes with Roop, from the very beginning, is calculated and only after evaluating the situation thoroughly does she make a decision about him. in his home for the first time, she appears uneasy, expecting him to make advances quicker than she would like. she is proven correct when Roop attempts to undress her in the bathroom. when he leaves her alone in the bath, she is relieved and relaxed enough to fall asleep. Claudine is tired - she says this outright later in the film - but doesn't want anyone to know. when she is able to be alone in a warm bath and undisturbed by one of her six children, she is able to rest; something she cannot even do later on when in bed with Roop. when Roop wakes her, Claudine attempts to cover herself while Roop gazes at her naked body. this represents the consumption of Black female bodies without regard even (and perhaps particularly) by Black men. when she tries to hide her body, Roop chuckles as if it was for him to enjoy anyway. here, Roop's gaze represents an intimate form of surveillance, that of the Black female body as it "is seen and inscribed under the rubric of privileged visual ideology; [where] the Black woman is seen, rather than heard, and her position in the New World, [is] as knowable racial-sexual object." ${ }^{37}$

Claudine and Roop's first date allows us a look at two sides of the white imagined deviant Black family, an absent Black father meeting a single Black mother without shared children to bind them. Roop's ability to move freely and flexibly through the world on the salary of a garbage man is founded in his lack of care, engagement, and commitment to his ex-partners and children whom he does not see. in this scene in particular, Roop attacks Claudine's position as a single mother of six at the age of 36 . here, Roop becomes an extension of the state by the way he attempts to police and chastise Claudine for her position. Patricia Hill Collins states that

${ }^{37}$ McKittrick, 49. 
"the image of the welfare mother provides ideological justifications for intersecting oppressions of race, gender, and class. ${ }^{״ 3}$ this sets up the advantage for the state to survey Black mothers. when Roop takes up the narrative of the state, he forces Claudine into a position of unique defense, what Darlene Clark Hine addresses as "[...] the Black woman's perennial concern with image, a justifiable concern born of centuries of vilification." ${ }^{39}$ Claudine refuses Roop's questions, telling him outright that she does not owe him anything. Claudine lets us know that her performance of the Black matriarch and welfare queen is relegated to the space of her home and that space only; that she will only play the role when her survival depends on it.

this first scene between Roop and Claudine works to preface the full throttle interrogation by welfare services and the invasive presence of the state in Black life. being a Black mother on welfare in New York is almost a given, and we know this because Roop and Claudine's first interaction (prior to the date) involves him asking her if she reports her work to the welfare office. as Simone Browne puts it, this demonstrates the presence of "surveillance in and of Black life as a fact of Blackness. ${ }^{.40}$ the following scene analysis looks at what it means for the state to reach its hand directly into the home and how Black women refuse to adhere to the narratives thrusted upon them by the same forces.

scene 2 - the visit from Miss Kabak (34:55-37:29)

in Claudine's apartment, she is ironing clothes in her kitchen when one of her sons runs into the room, shouting a warning that the social worker, Miss Kabak, has been spotted outside on her way to visit them. Claudine and her older daughter, Charlene, begin hiding kitchen

\footnotetext{
${ }^{38}$ Hill Collins, 79.

${ }^{39}$ Darlene Clark Hine, "Rape and the INner Lives of Black Women in the Middle West," 916.

${ }^{40}$ Browne, 6.
} 
appliances - an iron, a hot pot, a toaster - and replacing them with lesser quality versions. they also race to the living room to roll up the rug and hide it behind the window curtains. the preparation for Miss Kabak is well-rehearsed and everyone in the home knows what to do.

when Miss Kabak knocks on the apartment door, Charlene half opens it and announces to her mother that the social worker is there. Claudine stands behind the couch, responding with "well, don't just stand there. let her in" in an exaggerated manner so that Miss Kabak hears. when Miss Kabak enters the apartment, the children are arranged in the living room so that they appear as if they were waiting for her. she greets the children and Claudine and Charles leaves, ignoring her. Miss Kabak asks Claudine if she has been working (which she has) and Claudine refutes, saying she has not. as Miss Kabak persists on the topic of work, Claudine takes Miss Kabak through the small hallway and into the kitchen.

Miss Kabak begins to inquire about whether or not Claudine is seeing a man. according to her, a neighbor has reported seeing Roop coming and leaving the apartment complex. Claudine does not answer yes or no, but instead asks Miss Kabak whether or not she is expected to remain celibate in order to receive welfare. Miss Kabak continues to beg the question, insisting that Claudine must report anything that a man may be giving her - money, food, home goods, etc. while maneuvering Miss Kabak's questions, Claudine is careful to move items in the kitchen that may give away the presence of some of Roop's gifts (the appliances they hid in preparation for the visit). Miss Kabak goes on to request Claudine tell her what may have been gifted by Roop so that deductions can be made by the welfare office. rather than give up the gifts, Claudine makes up a lie about Roop bringing them beer and sodas and provides Miss Kabak with a dollar amount for her to deduct. Miss Kabak is unsatisfied by the low number and 
begs Claudine tell her more. the scene ends with Claudine directing the question right back at Miss Kabak, as she sips a beer.

from Hine, we know that "[...] Black women, as a rule, developed and adhered to a cult of secrecy, a culture of dissemblance, to protect the sanctity of inner aspects of their lives." ${ }^{\prime 1}$ this scene is one of the most blatant examples of such a culture. Claudine and her children seem to have established a very clear protocol for what to do when Miss Kabak arrives. social services are not a godsent, they are a means of survival and a vessel of state surveillance in their home. the scene begins with the second oldest son, Paul, running into the apartment to warn his mother that the social worker is arriving outside. everyone know what this means. Claudine and Charlene drop everything they are occupied with and begin to prepare the apartment for Miss Kabak's visit.

the preparation of the apartment is a particularly vital scene to the film - Gladys Knight's "Mr. Welfare Man" playing in the background. the two eldest Black women in the family carefully and precisely hide artifacts of their daily lives in order to throw off state suspicion of their status. in some ways, this can be taken to represent a spatial dissemblance; a familial understanding of "surveillance in and of Black life as a fact of Blackness." 42 the items they put away are items presumably brought into the home by Roop - an iron, a hot pot, a toaster, and a rug. the toaster is the most difficult for them to hide, as it is so large. this item may be the most notable that they hide away. in the beginning of the film, when Roop meets the children for the first time, the youngest son, Adam, breaks the toaster they had. as Roop's relationship with the children grows, Adam is the one most drawn to him, showing the most admiration. that Roop replaced the toaster Adam broke is a symbol of Roop's presence, not only in the home, but in the

\footnotetext{
${ }^{41}$ Hine, 915.

${ }^{42}$ Browne, 6.
} 
family. Claudine and Charlene hide the new toaster in the laundry basket under some clothes before Miss Kabak arrives.

just as the reaction to Miss Kabak pulling up was understood by the children, so too are their interactions with her - their body language and words scripted. Charlene half opens the front door, chain lock still fastened so Miss Kabak must be kept waiting. she announces Miss Kabak and Claudine ushers her in. this small maneuver of the door allows for an extra second to prepare the home if necessary, as well as allows a breath and resets the tone of the house after such frantic rearrangement.

when Miss Kabak enters the home, Claudine is sure to keep her occupied with discussion in order to keep her from searching the house too thoroughly. while Claudine and Miss Kabak chat, Charlene monitors them, watching her mother and how she handles the questions and accusations. in a number of moments, Claudine diverts Miss Kabak's attention away from things that she may be staring at just a little too long, and rope her into a conversation. Miss Kabak's first inquiries are about whether or not Claudine has been working. Claudine says she "aint been workin"43 and Miss Kabak regurgitates reasons why Claudine would have to tell her if she had been working, while Claudine diverts her path down the hall to the kitchen. rather than engage with the questions in a straightforward manner, Claudine moves her body and shifts the conversation in order to direct attention away from her work and her man. Miss Kabak probes Claudine for information about Roop and Claudine becomes stern, saying "now, you are not supposed to spy on us!"44 at the same time, Gladys Knight's song has faded, yet this line takes up for the absence of the lyric that reads "It's like a private eye for the FBI." 45 her explicit naming of surveillance here is what makes the scene so vital to the film and our conversation around

\footnotetext{
${ }^{43}$ Claudine 1974

${ }^{44}$ Ibid.

${ }^{45}$ Gladys Knight \& the Pips. Claudine (Original Motion Picture Soundtrack). (P) Buddha Records, 1974, audio.
} 
what happens when Black women recognize the powers that force them to perform an image. Claudine's work to dodge questions is an example of dissemblance of refusal. she does not disclose information that is not pertinent to her survival, yet still performs for the social worker as a broke Black mother in need, enough so to maintain her assistance.

the first scene between Miss Kabak and Claudine is almost less important than the ways Claudine and her children interpret Miss Kabak's presence in their life. we learn from them the role the government plays in their life - a necessary evil. Claudine's ability to subvert Miss Kabak's questions and eye is a testament to the dissemblance developed over time and through practice. this is a tool she passes on to her children, which guides us to our final film analysis between Claudine and her oldest son, Charles.

scene 3 - Charles vs. Claudine (1:13:10-1:15:10)

after discovering Roop's disappearance, Claudine is devastated. sitting on the stoop of their apartment, Claudine smokes a cigarette and drinks one of the beers featured in the first scene with Miss Kabak. Charles approaches her and begins chastising her for her failed relationship with Roop. Charles verbally attacks Claudine, blaming her for the failures of his siblings, for their position in poverty. Charles barks at his mother that she should have killed them before they had to grow up in an oppressive world. Claudine fights back, attempting to instill in him the understanding that she does everything she can to keep them alive.

previously in the film, Claudine had found Charles organizing with Black radicals who were planning direct actions against the city police and government. in their organizing space, Claudine begs Charles to leave and come home, knowing that the work he is doing will surely lead him to either prison or death. Charles barks at his mother, that he would rather die than have 
to hid the way she does from the state - referencing the performance she must engage in for welfare. Charles believes his mother to be a coward in the face of the state.

Claudine asserts that she is scared and she is tired, and that Charles ought to be scared too. where he insists that "frightened people can't change anything," she challenges that "if you ain't scared, you ain't got no need for guts." ${ }^{46}$ she says "I'm scared all the time, but I do my job." Charles has no way to refute this, he simply asks her her next move and she answers that she's just going to keep on doing what she needs to do.

this scene between Charles and Claudine can be explained in many ways by Hortense Spillers' analysis of the controlling narrative that "the African-american female's 'dominance' and 'strength' come to be interpreted by later generations - both white and black, oddly enough as a pathology, as an instrument of castration." ${ }^{47}$ Charles feels as though his mother's actions and decisions are that of a Black female pathology, where she has taken away his power as a Black man by giving him a life that requires submission. he attempts to claim himself in a way that negates her care and persistence in keeping him alive. Spillers talks about the lack of claim that Black mothers have of their children, being that Black women specifically have no locus of control. a Black woman, according to Spillers, cannot lay claim to anything, not even her own life. Claudine seems to have come to terms with that in some ways, begging Charles to see that she only does what she can do in the hopes they may be able to do better. Claudine knows that she has lost her children, even as she works tirelessly to take care of them. the camera angling of this scene, with Charles standing over Claudine, yelling down at her, is the dynamic Spillers assesses when talking about the Black family. there is no lineage, only Black mothers who try themselves into exhaustion, and Black children who are doomed to some fate they can't choose.

\footnotetext{
${ }^{46}$ Claudine 1974.

${ }^{47}$ Spillers, 218.
} 
Charles' helplessness manifests itself in him policing his own mother, not unlike the state powers she performs for every day.

this scene is rich with dialogue about what it means for Claudine to be a Black mother in the 70s. the man she believed to be her son is refusing her care and commitment to keeping him alive; more than that, he is antagonizing her for those very decisions. Claudine recognizes and tells us exactly her predicament - though she wholly knows the inevitability of her failure to protect her children, it is literally all she can do to try.

\section{conclusion}

the art of dissemblance and Black feminist refusal is attributed to and produced by the racialized and gendered schema of the surveillance of Black life. surveillance mechanisms of the state manifest themselves in the everyday (the policing of race and gender by law enforcement) and in the most intimate parts of society designed to monitor and control Black life (social services). Black women have developed dissemblance as a tool to preserve themselves and their families from the violence and subjugation of the state. Claudine and Dorothy engage with state authorities in different ways, yet one thread connects them across complexities: their ability to lift and lower the veil of secrecy and preservation; taking control from the powers that be, unbeknownst to them. not only do these women exhibit a radical subversion, but they also pass down the knowledge to their children so that they too may be able to preserve themselves as state surveillance infiltrates their lives. 


\section{bibliography}

Browne, Simone. "Introduction, and Other Dark Matters." In Dark Matters: On the Surveillance of Blackness. Durham: Duke University Press Books, 2015.

---. "Chapter 3: BRanding Blackness.” In Dark Matters: On the Surveillance of Blackness. Durham: Duke University Press Books, 2015.

---. “Epilogue: When Blackness Enters the Frame.” In Dark Matters: On the Surveillance of Blackness. Durham: Duke University Press Books, 2015.

Simone Browne uses Dark Matters to explore the ways in which the carceral state develops and maintains control over Black life. "Introduction, and Other Matters" lays out the nature of surveillance as tool of the state for control and meaning making. by examining white supremacist colonial technologies of branding and the ownership of the body, "Chapter 3: BrRanding Blackness" gives context for the race-making process that produces understandings of Black bodies as nonhuman. "Epilogue: When Blackness Enters the Frame" concludes Dark Matters with an exploration of the ways technologies form our understandings and perceptions of self; and characterize the ways in which Black people can and do subvert the white gaze. this work assists my thesis in crafting a lens through which to understand the development of "surveillance in and of Black life as a fact of Blackness." (6)

Crawley, Ashon. "Otherwise, Ferguson.” Interfictions no. 4.

de Certeau, Michel. "IV: Foucault and Bourdieu." In The Practice of Everyday Life. 2nd ed. University of California Press, 1984.

Eversley, Shelly, et al. “'Whatcha Gonna Do?': Revisiting 'Mama's Baby, Papa's Maybe: An American Grammar Book': A Conversation with Hortense Spillers, Saidiya Hartman, Farah Jasmine Griffin, Shelly Eversley, \& Jennifer L. Morgan.” Women 's Studies Quarterly. vol. 35, no. 1/2 (Spring - Summer 2007): 299-309.

Ford, Tanisha C. "SNCC Women, Denim, and the Politics of Dress." The Journal of Southern History. 79, no. 3 (August 2013): 625-58.

Gerima, Haile. Bush Mama. Film. Directed by Haile Gerima (1979; Los Angeles: University of California, Los Angeles, 1979). Medium.

Haley, Sarah. “Chapter 2: Convict Leasing, (Re)Production, and Gendered Racial Terror.” In No

Mercy Here: Gender, Punishment, and the Making of Jim Crow Modernity. Chapel Hill: The University of North Carolina Press, 2016. 
---. “Chapter 5: Sabotage and Black Radical Feminist Refusal.” In No Mercy Here: Gender, Punishment, and the Making of Jim Crow Modernity. Chapel Hill: The University of North Carolina Press, 2016.

Hill Collins, Patricia. "Chapter 4: Mammies, Matriarchs, and Other Controlling Images." In Black Feminist Thought: Knowledge, Consciousness, and the Politics of Empowerment. Revised, 10th Anniv., 2nd edition. New York: Routledge, 1999.

Patricia Hill Collins provides a lens through which to view the cartographies of Black women in the US, as raced and gendered beings. in this chapter, she depicts constructed images used to survey and police Black women in the neoliberal context of the modern state. I use this work to frame the narratives of controlling images projected onto raced and gendered bodies in the every day.

Hine, Darlene Clark. "Rape and the Inner Lives of Black Women in the Middle West." Signs, no. 4 (Summer, 1989): 912-920.

Kumar, Deepa and Arun Kundnani. "Race, Surveillance, and Empire." International Socialist Review, no. 96 (2015): 18-44.

this article addresses the increasingly pervasive nature of state surveillance, particularly as it pertains to the monitoring of Black and Muslim americans. Kumar and Kundnani centralize the concept of a "social wage" of whiteness, which allows national security (coded as surveillance) to flourish without challenge. they demonstrate the ways ethnographic data collection, law and policy, and colonial surveillance techniques act as modern tools of biopolitical control. this work is seminal to understanding the ways race functions as a tool of surveillance and national security.

McKittrick, Katherine. "Introduction: Geographic Stories.” In Demonic Grounds: Black Women And The Cartographies Of Struggle. University Of Minnesota Press, 2006.

---. "Chapter 2: The Last Place They Thought of: Black Women's Geographies." In Demonic Grounds: Black Women And The Cartographies Of Struggle. University Of Minnesota Press, 2006.

Philip, NourbeSe M. "Dis Place - the Space Between." In A Genealogy of Resistance and Other Essays. Feminist Measures, eds. Lyn Keller and Cristanne Miller, University of Michigan Press, 1994.

Pine, Lester and Tina Pine. Claudine. Film. Directed by John Berry (1974; Third World Cinema,

1974). Medium. 
Shabazz, Rashad. "Carceral Matters: An Introduction.” In Spatializing Blackness: Architectures of Confinement and Black Masculinity in Chicago. 1st edition. Urbana: University of Illinois Press, 2015.

Spillers, Hortense J. “Chapter 8: Mama's Baby, Papa's Maybe: An American Grammar Book." In Black, White, and in Color: Essays on American Literature and Culture. 1st edition. Chicago: University Of Chicago Press, 2003.

Trudy. "Misogyny, In General vs. Anti-Black Misogyny (Misogynoir), Specifically." Gradient Lair (September 11, 2013). Web.

Weheliye, Alexander G. "Introduction: Now." In Habeas Viscus: Racializing Assemblages, Biopolitics, and Black Feminist Theories of the Human. Durham: Duke University Press Books, 2014.

---. "Chapter 3: Assemblages: Articulation." In Habeas Viscus: Racializing Assemblages, Biopolitics, and Black Feminist Theories of the Human. Durham: Duke University Press Books, 2014.

Alexander Weheliye uses this work to locate the gap in discourse between bare life and biopolitics. In Habeas Viscus, he posits that pseudo-biological constructs of race and gender invent categories of human, not-quite-human, and non-human. The social organizations used to politically classify and caste people is one that materializes specifically "racialized assemblages", which are employed on the flesh. The "Introduction: Now" names the vacancy of nuance in bare life and biopolitical discourses, and "Chapter 4: Assemblages: Articulation" calls into question the naturalism assumed in racial assemblages as we understand them in the context of the modern state. Habeas Viscus operates within my thesis as a foundational examination of what it is to be rendered nonhuman through understood processes of gendered racialization.

Wilderson III, Frank B. "Chapter 4: Cinematic Unrest: Bush Mama and the Black Liberation Army." In Red, White \& Black: Cinema and the Structure of U.S. Antagonisms. Durham, NC: Duke University Press Books, 2010. 